О. В. Мохначева

канд. филол. наук, доцент

\title{
ГРАНИЦЫ ЖАНРА В АВТОБИОГРАФИИ В. В. НАБОКОВА «ПАМЯТЬ, ГОВОРИ»
}

У статті розглянуто своєрідність автобіографії як літературного жанру, етапи його формування та спещифіка втілення в творі В. Набокова «Пам'ять, говори». Простежено головні теми книги, авторські способи створення «особливої реальності» як ознаки жанру, визначено самоіронію як якісний знак письма й один із найважливіших принципів вираження авторської самосвідомості.

Как утверждает один из лидеров современной английской литературы Мартин Эмис в своем романе «Ехреrience» (1975), «западная литература сейчас переживает этап высокой автобиографии с глубоким самокопанием». Этим оригинальным суждением Эмис одновременно отмечает и характерное для нынешнего художественного процесса обращение к культуре предшествующих эпох в качестве строительного материала для постмодернистских текстов, и заметную склонность к анализу жизненной истории, предшествующей как определенным явлениям культурной жизни, так и сформировавшей мировоззрение отдельных писателей. В этом смысле Эмис говорит о принципе воссоздания фактов действительности по тому же принципу, что и в литературном жанре автобиографии, получившем в последнее время распространение и завоевавшем особенный интерес.

По мнению современного исследователя, «интерес к автобиографии обусловлен, главным образом, логикой теоретико-литературного процесса 
$\mathrm{XX}$ века и спецификой самого жанра» [1]. Автобиография отразила в себе потребность самооценки и анализа, построенного на корреляции своего видения предмета, в частности, это «феномен, отображающий стремление людей в той или иной творческой форме выразить свою личную жизненную историю» [9]. В этом смысле современная литература охотно принимает на себя «универсальную» сверхзадачу автобиографии - самовыделение индивида в историческом пространстве-времени. Эту задачу Л. Баткин называет «субстанциональным оправданием автобиографизма как такового» [3].

Жанр автобиографии возник поздно, около 200 лет назад, и широко распространился в мировой литературе. Он активно изучался такими западными учеными, как Э. Брюс, Г. Миш, Ф. Лежён, Дж. Олни и другие. В отечественном литературоведении в разных аспектах ставились и решались проблемы жанрового своеобразия автобиографии в работах таких авторов, как Е. М. Апенко, Г. И. Берестнев, М. М. Бахтин, Л. М. Баткин, Ф. Знанецкий, Ю. М. Лотман, Г. Е. Померанцева, А. Г. Тартаковский, Б. М. Эйхенбаум и др. Среди них особо выделяется исследование Л. Я. Гинзбург «О психологической прозе».

Процесс углубленного и активного изучения жанра начался в 50-е годы XX века после выхода в свет статьи французского философа Ж. Гюсдорфа «Условия и границы автобиографии» и деятельности Ф. Лежёна, основавшего «Французскую Ассоциацию в защиту автобиографии и автобиографического наследия», деятельность которой направлена на изучение, сохранение и популяризацию соответствующих текстов. Ф. Лежёну принадлежит жанровое определение автобиографии: «... мы называем автобиографией ретроспективное повествование о себе, первостепенное значение в котором имеют события частной жизни и история становления личности рассказчика» [1].

Признаки автобиографии как литературного жанра определены самим его названием: это прозаический текст, в котором автор, как правило, последовательно рассказывает о событиях собственной жизни. «Питательной средой для развития автобиографии стала западноевропейская культура нового времени с ее духом самоанализа и индивидуалистическим мироощущением» $[7,12]$. В основе автобиографического жизнеописания лежит стремление осмыслить прожитую жизнь как целое, придать эмпирическому существованию оформленность и связность, при этом пишущий литературную автобиографию нередко прибегает к вымыслу, он «дописывает» и «переписывает» свою жизнь, делая ее логичнее, целенаправленнее. Автобиография - это всегда акт преодоления уходящего времени, попытка вернуться в собственное детство, юность, воскресить наиболее значительные и памятные отрезки жизни - как бы прожить жизнь сначала» $[7,12]$.

Жанровыми характеристиками автобиографии можно считать такие признаки, как двойная хронология жизненного опыта («изменение от прошлого к будущему и противоположное движение - от ожидания (или воо-

$$
-112-
$$


бражения) к воспоминанию через живое настоящее» [9]); одновременное пребывание в душе автора разнообразных образов, что Поль Рикер называет «множественностью самовосприятия»; иносказание, ориентированное на личностные изменения; диалогичность (обращенность повествования к Другому - к Богу, к читателю, к значимым людям, к себе в разных образах [9]), выраженное авторство, произвольная авторская форма изложения. Особенно подчеркнем три формы нацеленности настоящего, присущие рассказу о себе, которые выделяет Поль Рикер - настоящее прошлого, или память, настоящее будущего, или ожидание, настоящее настоящего, или внимание [10].

Специфика автобиографии как разновидности литературы в первую очередь заключается в тонкостях работы этих трех временных и психологических пространств текста, в столкновении и взаимодействии которых и проявляются с таким трудом воспроизводимые личные сообщения. «Автобиография, всегда подразумевающая наличие особого текстового пространства и времени, своеобразные выразительные средства, позволяет избежать приписывания людям тотального «кризиса идентичности», она дает возможность исследователю увидеть то, как человеческое самосознание решительно свидетельствует само о себе - без внешних посредников и интерпретаторов» [1]. Важно учесть при этом, что художественная автобиография нередко не только не скрывает субъективности изложения происходящего, но отличается рефлексией особого плана - в виде иронического дистанцированного самонаблюдения, что еще в большей степени обозначает условность изображаемых в ней событий.

Как художественно-документальный жанр, автобиография обладает двумя формами художественной интерпретации: с одной стороны, ей присущ «лиризм (передача мыслей и чувств автора вымышленными персонажами), с другой - творческое преломление фактов собственной жизни в художественных повествованиях» [11]. Основная категория документального жанра - достоверность, однако это категория в автобиографии относительная, поскольку в ней излагаются факты, переосмысленные и переоцененные автором. Автор здесь одновременно является героем произведения, реальные факты его жизни в их хронологической последовательности - сюжетом. Л. Я. Гинзбург пишет: «Особое качество документальной литературы - в той установке на подлинность, ощущение которой не покидает читателя, но которая далеко не всегда равна фактической точности». Некий фермент «недостоверности» заложен в самом существе жанра. Когда начинается выбор, оценка, «угол зрения перестраивает материал» [11].

В связи с этим, критики отмечают, что как культурный феномен автобиография имеет ряд противоречий:

- противоречие между стремлением автора создать свой собственный образ и апелляцией к позиции Другого (читателя), который должен этот образ выстроить и завершить; 
- противоречие между исторической документальностью и субъективной версией событий, определяемой «Я-концепцией» пишущего. Это противоречие часто разрешается в пользу субъективной версии в силу того, что автор практически всегда видит в себе «положительного героя»;

- противоречие между стремлением автора собственной биографии выработать самоидентичность (целостность Я) и цепью сменяющихся самооценок, которые неизбежны в тексте, повествующем об «истории жизни»;

- противоречие между Я-субъектом, выступающим как авторповествователь, и Я-объектом, выступающим в качестве предмета описания: характеристик, оценок, мнений [1].

Обращение писателя к документальным жанрам и, в частности, к автобиографии, нередкое явление в культуре XX века, имеющее определенную традицию и условия. Автобиография нового времени - чаще всего художественное переосмысление жизненного опыта пишущего, попытка творчески проанализировать собственное движение в мире вымысла, а не стремление беспристрастно изложить этапы собственной биографии. По этому поводу В. Набоков писал, что как жанр биография, например, невозможна: «Разве можно совершенно реально представить себе жизнь другого, воскресить ее в своем воображении в неприкосновенном виде, безупречно отразить на бумаге? Сомневаюсь в этом; думается, уже сама мысль, направляя свой луч на историю жизни человека, ее неизбежно искажает. Все это будет лишь правдоподобие, а не правда, которую мы чувствуем». Автобиография - иное дело; относительно книги «Другие берега» Набоков следующим образом определил круг писательского интереса: «Это мемуары и правда. Разумеется, они в большей степени построены на отборе. Что интересовало меня, так это тематические линии моей жизни в той мере, в которой они сходны с линиями литературными. Мемуары становятся местом встречи безличной формы искусства и в высшей степени личной истории жизни... Это литературный подход к моему собственному прошлому».

В наследии В. Набокова несколько версий автобиографического романа - «Убедительные свидетельства» (1951) - первый английский вариант, русская версия «Другие берега» (1954) и англоязычная книга «Память, говори» (1967), дополненная и видоизмененная. «Память, говори», таким образом, представляет собой окончательный вариант автобиографии Набокова, которую автор существенно дополнил и переделал в сравнении с предыдущими.

В «Предисловии» автор оговаривает главный принцип построения книги: «она представляет собой собрание систематически связанных личных воспоминаний, простирающихся географически от Санкт-Петербурга до Сен-Назера и охватывающих тридцать семь лет, с августа 1903-го по май 1940-го, с лишь немногими вылазками в более позднее пространствовремя» $[8,317]$. 
Выделение временных координат вполне естественно для большого автобиографического произведения, последовательно описывающего жизнь одного человека. Однако главные темы книги - размышление о смерти и жизни, о времени и о вечности, с ними связаны сюжеты воспоминаний. «В согласии с эстетикой обмана, которому Набоков придает статус высшего принципа, очевидные, казалось бы, утверждения уходят в сторону и скрывают истинный умысел автора», - отмечает В. Е. Александров [2, 33], определяя как художественную стратегию стремление Набокова затемнить смыслы, скрыть за масками-Арлекинами не только свои важнейшие переживания, личные эмоции, но и избежать линейного пересказа хронологии событий согласно логике здравого смысла. «Биографию здравого смысла читать отвратительно», - напишет Набоков в лекции «Искусство литературы и здравый смысл». Как в своих романах, так и в автобиографии Набоков ставил перед собой задачу сотворения особенной реальности, в которой условность и реальность в равной степени участвуют в моделировании пространства текста. Его автобиографические книги отражают не столько факты жизни писателя, сколько демонстрируют комплекс его взглядов и убеждений, их зарождение, трансформацию и «переливы». Метафора, игра со смыслами, одновременно точность рассказывания и оригинальность трактовки, позволяющая «умножать» и затемнять смыслы - вот ориентиры набоковского письма, характерного и для автобиографии.

Исследователи не раз отмечали особую склонность Набокова к закрытости, игре с намеками, явному или слегка намеченному обману. «В его мире слишком много табу, слишком он выстроен и организован, что сообщает ему некоторую даже неестественность. Все, что нам удается узнать о его взглядах, привычках, пристрастиях и чувствах, всегда выуживается с трудом из каких-то придаточных предложений, собирается по крохам - все самое заветное заткано плотной сетью недомолвок», - замечает критик [6, 154]. Это касается и его автобиографии.

Автобиография Набокова при соблюдении всех внешних жанровых признаков отличается от себе подобных тем, что ее главный объект сознательно уведен с полагающегося ему доминирующего места: центральная тема мемуаров не история жизни определенного лица, а раздумья и предположения о жизни до рождения и после смерти. Неслучайно связанные с этой темой куски текста появляются во второй версии книги и доминируют в последующем издании.

Эстетическое кредо Набокова связано с концепцией реальности, построенной на нерасчленимости триединства «реальность-воображениепамять», на утверждении: «Воображение - это форма памяти». «Начиная с романа «Другие берега», «страстная энергия памяти» обрела статус творческой доминанты» $[4,35]$, под влиянием которой выстраивается логика повествования автобиографического текста у Набокова. Предмет истинного ис- 
кусства по Набокову - это жизнь воображения, понимаемого как форма памяти, «вобравшей в себя личный и культурный опыт человека, а значит, не только его личные воспоминания, но и память о том необъятном мире художественного вымысла, который представляет ему искусство» $[4,36]$.

Образ жизненного странствия и концепция человеческого сознания связаны в книге и творчестве Набокова с проблемой времени, с пониманием зарождения самосознания как процесса, обусловленного временем и окружением: «Время без сознания - мир низших животных; время плюс сознание - человек; сознание без времени - некое еще более высокое состояние». Сознание как источник воображения, как связующая событийная основа лежит во главе угла набоковского раздумья о своем прошлом.

Отличительной чертой автобиографии Набокова является кроме всего прочего остроумие, блистательная ирония и самоирония - качественный знак его письма, важнейший принцип выражения авторского сознания. Чего стоит, например, следующий фрагмент в контексте воспоминаний о предках Набокова, оставивших ему наследство, экспроприированное во время революции: «Нижеследующий пассаж предназначается не для широкого читателя, но для узкого остолопа, потерявшего деньги в какомнибудь «крахе» и потому полагающего, что понимает меня» $[8,373]$. Для Набокова совершенно не характерно заигрывание с читателем, в его версии нет «апелляции к позиции Другого», что придает особую тональность книге - сдержанной искренности и горьковатой насмешки над собственной судьбой. Эта присущая автобиографии «Память, говори» тональность, характерная и для прозы Набокова в целом, многих настраивала против него, но стала его «фирменным знаком», благодаря которому его голос различим среди бесконечного множества писателей разных эпох и поколений.

Автобиография - крайне сложная, «даже изощренная» литературная форма, она появляется в истории культуры поздно, фактически одновременно с тем, как в литературной жизни «кристаллизуется полноценная фигура автора» (Ф. Лежён). Этот жанр - воплощение самостоятельности и осознанной позиции индивида, его зрелости и эстетической ответственности. Развитие жанра связано со стремлением расширить возможности авторского голоса и способа письма - быть одновременно и темой, и предметом автобиографии, и при этом оставаться ее автором. Отсюда «расцвет косвенных писательских стратегий», отсюда попытки подорвать жанр и одновременно открыть в нем новые возможности. Вот почему в автобиографиях больших писателей, особенно, таких как Набоков, заметны следы не только их многогранного таланта и диапазон творческих поисков, но и отголоски философских, эстетических и др. проблем эпохи, реализованных в форме «литературы как невозможности», как обозначил этот жанр его самый преданный апологет Ф. Лежён, и стремление найти новые формы и поэтические средства выражения.

$$
-116-
$$




\section{Список использованной литературы}

1. Автобиография: философско-культурологический анализ. Диссертация. http://www. nauka-shop. com/mod/shop/productID/54680/

2. Александров В. Е. Набоков и потусторонность: метафизика, этика, эстетика. СПб: Алетейя, 1999. - 320 с.

3. Баткин Л. М. Европейский человек наедине с собой. - М., 2000. -230 с.

4. Злочевская А. В. Роман В. Набокова «Ада» в контексте русской литературной традиции // Вестник МГУ. - Сер.9. Филология. - 2001. - № 2. - С. 34-46.

5. Знанецкий Ф. Мемуары как объект исследования // Социологические исследования. - 1995. - №4. - С. 106-107.

6. Иванова Е. Владимир Набоков: выломавшее себя звено // Литературная учеба. - 1989. - № 6. - С. 153-161.

7. Литературный энциклопедический словарь / Под ред. Кожевникова В. М., Николаева П. А. - М.: Сов. энциклопедия, 1987. - 752 с.

8. Набоков В. Память, говори // Набоков В. Американский период. Соб. соч. в 5ти тт. - СПб: Симпозиум, 1999. - Т.5. - С.314-597.

9. Описание ЛЖИ - становление автобиографического жанра http://www. zadanie. com/2007/opisanie-lzhi-\%E2\%80\%93-stanovlenie-avtobiograficheskogozhanra/

10. Рикер П. Время и рассказ. - М.-СПб.: Университетская книга, 1999. - 200 с.

11. Яркова А. В. Жанр автобиографического романа в творчестве Б. К. Зайцева http://www. yarkova. lodya. ru/Alla52. htm.

\section{Summary}

The article studies the peculiarities, of autobiography as a literary genre, its stages and its features in V. Nabokov's work «Memory, speak». It deals with the main topics of the novel, the author's way of creating «special reality» as the genre's mark and self-irony as one of the most important principles to express author's selfconscience. 